\title{
STUDY ON OFFSHORE SAND USE AS PART OF THE SUBSTITUTION OF RIVER SAND AND M SAND
}

\section{NEETHU $S^{1} \&$ D TENSING ${ }^{2}$}

${ }^{I}$ Assistant Professor, Department of Civil Engineering, MES College of Engineering and Technology, Kunnukara, Ernakulam

${ }^{2}$ Professor, Department of Civil Engineering, Karunya Institute of Technology and Sciences, Coimbatore

\begin{tabular}{l} 
ABSTRACT \\
The purpose of the study is to test the physical, chemical and structural characteristics of dredged offshore sand and to \\
evaluate the extent of partial use as a replacement for river sand and M sand. For testing the physical and chemical \\
properties, experiments like Grading, determination of Chlorides, Shell content and Organic matters were done. For \\
analyzing the Structural properties various experiments like Sieve analysis, Gap grading, determinations of Compressive \\
strength, Flexural strength, Rapid chloride penetration test (RCPT), Water absorption test and Alkalinity test were done. \\
The amount of chloride, shell content, organic content were as per the standards. The compressive strength and flexural \\
strength of concrete with graded sand were found to be comparable to that of concrete with River sand or M Sand. The \\
RCPT results show that the average current passing through the off shore sand was within the range specified by ASTM \\
for conventional concrete. Water absorption of concrete specimens cast with offshore sand was less, compared to \\
specimens cast with graded offshore sand. The alkalinity of all the concrete specimens with graded offshore sand was \\
within the permissible limits. Offshore sand can be used for making concrete when partially replaced with river sand or M \\
Sand. \\
\begin{tabular}{l} 
KEYWORDS: Offshore Sand; Chloride Content; Shell Content; Gap Grading; Durability; Water Absorption; Alkalinity \\
\hline
\end{tabular} \\
\begin{tabular}{|l|c|}
\hline NOMENCLATURE \\
\hline OSS
\end{tabular} \\
\hline MS
\end{tabular}

Received: Jun 06, 2020; Accepted: Jun 26, 2020; Published: Jul 20, 2020; Paper Id.: IJMPERDJUN2020390

\section{INTRODUCTION}

Owing to the ever-increasing growth of the construction industry, demand for sand as a building material has now increased. Now a day's River sand and M sand has become the most commonly used fine aggregate in India and over-exploitation of river sand has resulted in irreparable harm to the soil, water, biotic and social / human ecosystems associated with many of the world's river system and water table even goes deeper and eventually dry. Sand mining is now becoming an environmental issue in India. River sand is becoming very scarce and the government has banned the removal of sand from the beds of rivers. So we need to find out an alternative to river sand if we have to carry on with the construction industry smoothly for the years to come. Offshore sand was collected from the coastal areas of Cochin for the research work. The seaward sand was excavated to increase the Cochin harbor's ocean bed depth for ship entry. The offshore sand collected for the project work had been subjected to rain for nearly a year. Since river sand is a product in demand, attempts have been made to use $\mathrm{M}$ sand as a fractional substitution with sea sand to improve its property for creating good concrete. M sand used in this study is 
obtained from Coimbatore.

\section{LITERATURE REVIEW}

Ajithkumar. S, et.al. (2018) in their paper used materials such as slag, m-sand, crushed sand, sea sand etc. instead of river sand. In this paper, sea sand being replaced fractionally with river sand in quantum of 20\%, 30\%, 60\% and 100\% by weight. When 30 per cent of sea sand was replaced by river sand, compressive strength improved and 20 per cent of sea sand replaced with river sand, tensile strength improved compared to conventional concrete. V. Kanthe, et.al (2018) used sea sand samples before and after mineral extraction and partially replaced with $20 \%$ by weight of river sand and analyzed using energy-dispersive X-ray analysis. Authors concluded that the compressive strength of concrete produced from sea sand after mineral extraction was $0.5 \%$ higher than that of concrete with sea sand at 7, 14 and 28 days prior to extraction. $\mathrm{V}$ Mahalakshmi, et.al. (2017) used sea sand by removing the chloride content using sand washing technique. The authors found that the compressive strength and split tensile strength of the concrete with filtered sand was greater at 7, 14 and 28 days than that of unpurified sand concrete. S.E.Mousavi, (2016) studied the Concrete specimens made with a combination of bottom ash, marine sand and river sand which were cured in sea water. Authors found that compressive strength of concrete specimens with 50\% bottom ash concrete had shown lesser value compared to the conventional M30 grade concrete specimens. N.P Ratnayake, et.al. (2014) found that the rate of hardening concrete made with Quarry dust is relatively rapid compared with the specimen made using river sand, sea sand and mixed sand concrete. Compared to river sand, concrete created using Sea sand has reasonable compressive strength and much higher compared to quarry dust. Clcontent in sea sand before natural or artificial washing reaches the permissible limit and is therefore unsafe for Reinforced cement concrete. Sivaramalu Naidu, et.al. (2013) studied chemical and geotechnical properties of sea sand like alkalinity, hardness, $\mathrm{pH}$, specific gravity, bulking of sand, angle of internal friction and found that all the results are acceptable with regard to the allowable limits as per IS code. D A R Dolage, et.al (2013) found that the sand collected from a distance of 2-7 $\mathrm{km}$ from the shore had less chloride content and that the compressive strength and chloride content were within the permissible limits. J Limeira, et al. (2012) researched dredged marine sand (DMS) as an addition or substitution of fine aggregate in different mixes of cement paste and mortar, and found a replacement of 25 percent as an optimal substitution. S.Islam, et.al. (2012) used accelerated corrosion test to analyze the properties of reinforced concrete with offshore sand and found that $\mathrm{M} 20$ grade concrete with $0.3 \% \mathrm{Cl}_{-}$in the sand underwent significant corrosion.

From the above stated literature review, it is evident that several experiments have to be done to know more about the structural properties of offshore sand. The main objectives of this experimental research involves evaluation of the related properties of offshore sand, suitability of dredged offshore sand for concreting, and enhancing the properties of offshore sand with river sand and M sand as a partial replacement.

\section{MATERIALS AND METHODS}

An experimental analysis was carried out from the sample collected at Puthuvypin port area, Cochin. For the clearance of the shipping channel, the sand was dredged 7-8 km from the sea shore and is collected nearby, which has been subjected to rain for over a year. Experiments include physical, chemical and structural properties of offshore sand.

\section{Material Properties}

The properties of materials were compared with the standards as shown in the table 1 
Table 1 Standards Adhered for Material Properties

\begin{tabular}{|c|l|c|}
\hline Sl. No & \multicolumn{1}{|c|}{ Properties } & Conforming to \\
\hline 1 & Grading & IS 383 - 1970 \\
\hline 2 & Organic matter & ASTM D 2974 \\
\hline 3 & Chloride content & IS: 3025 (part 32) - Reaffirmed 2003 \\
\hline 4 & Shell content & BS 882: 1992 \\
\hline 5 & Water absorption & ASTM C 140 \\
\hline 6 & Alkalinity & ASTM D \\
\hline 7 & RCPT & ASTM C 1202 \\
\hline
\end{tabular}

\section{TEST SPECIMENS FOR EXPERIMENTAL STUDY}

Cubes, cylinders and prisms of grade M20, M25, M30 were cast using offshore sand, river sand, M sand, graded river sand (Offshore sand replaced with 10\%, 20\% and 30\% by weight of river sand) and graded M sand (Offshore sand replaced with $10 \%, 20 \%$ and $30 \%$ by weight of M Sand) and cured for 28 days. TheS cubes were tested in Compression Testing Machine of capacity 250T and cylinders \& prisms were tested in Universal Testing Machine of capacity 100T.

\section{RESULTS AND DISCUSSIONS}

\section{Grading}

The graphs are drawn between fineness of sand and sieve size to study the grading of fine aggregate. Fig. 1 shows the curves of offshore sand. From the graph, it was found that the curve for offshore sand deviate much from the limits specified by the curves obtained for IS 383 - 1970 specifications in the sieve size less than 300 microns. Hence the offshore sand was found to be too fine than Zone IV which is unsuitable for construction purposes.

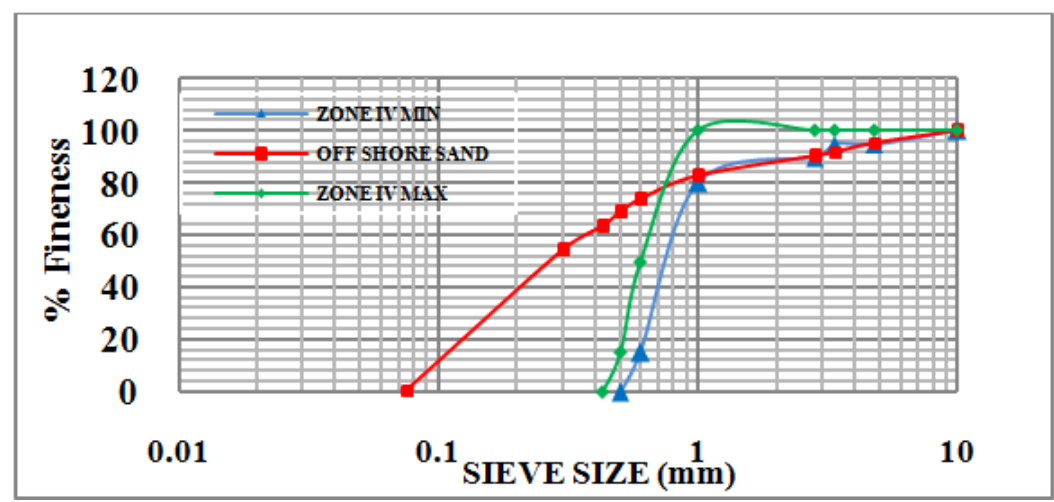

Figure 1: Grading of Offshore Sand.

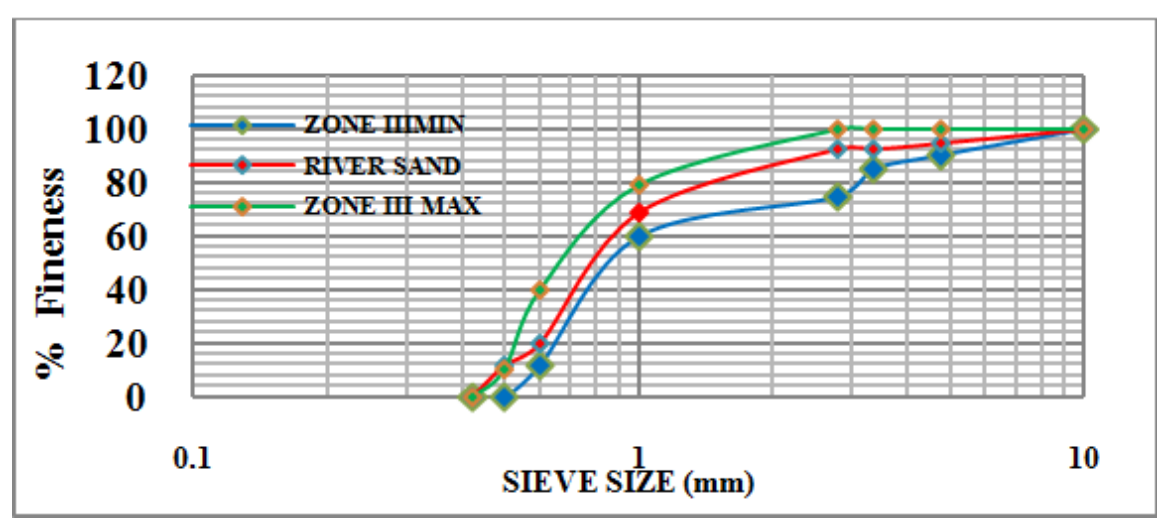

Figure 2: Grading of Graded River Sand. 
Approximately 50 per cent of offshore sand particles were found to be smaller than 300 microns in size that are unacceptable for concrete usage. Therefore particles smaller than 300 microns of offshore sand is removed. River sand or M sand moving through 300 microns is mixed in place of the discarded particles by about 20 percent with offshore sand separately to improve the properties of fine concrete aggregate. Sieve analysis was performed to analyze the new sand compositions.

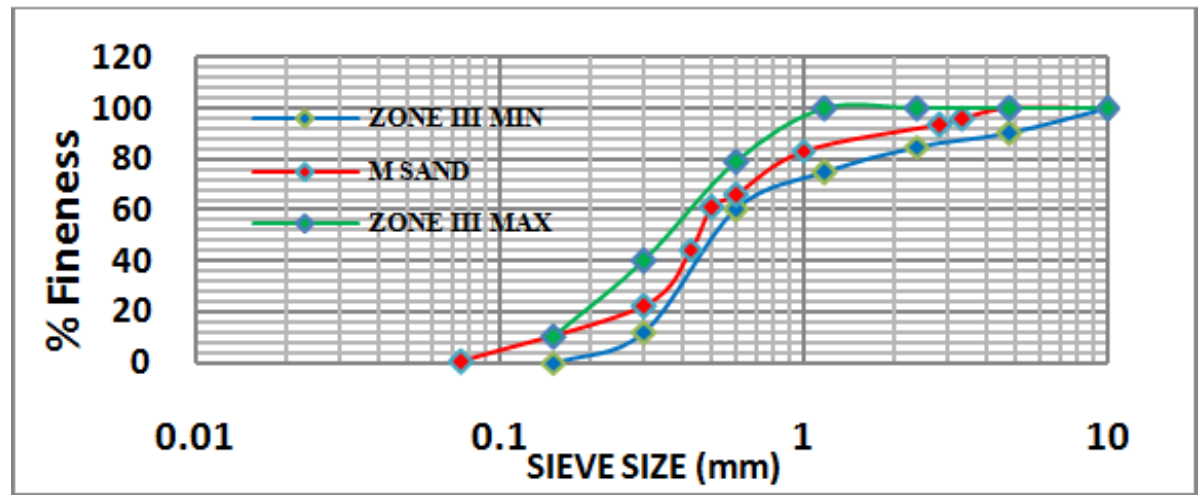

Figure 3: Grading of Graded M Sand.

This test was performed to determine the organic content in the offshore sand. The organic content is the ratio between percentages of organic matter in a given mass of sand to the weight of the dry sand. The organic content in the offshore sand was found to be 1\% which is in agreement with ASTM D 2974.

\section{Chlorides}

$0.014 \%$ of chlorides were found in offshore sand which is marginally higher than the standard limit of $0.01 \%$ can be ignored.

\section{Shell Content}

The offshore sand was found to have $1.1 \%$ of shell which is very low as per the standard limits.

\section{Water Absorption}

The proportion of water absorbed by various specimens produced from offshore sand, river sand, M sand, graded river sand and graded $\mathrm{M}$ sand and the result is shown in fig 4(a) and fig 4(b).

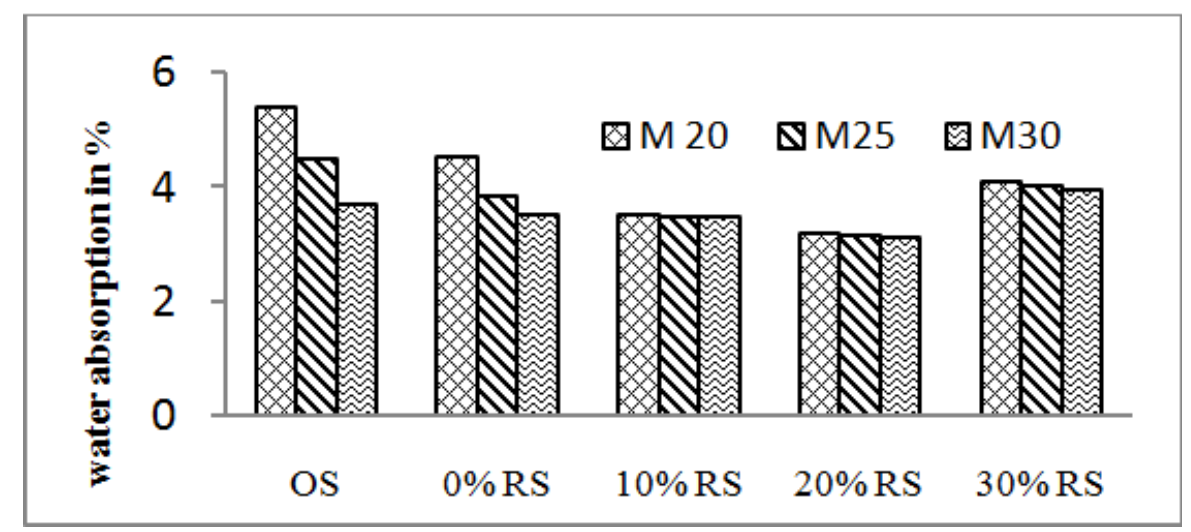

Figure 4(a): Concrete with RS. 


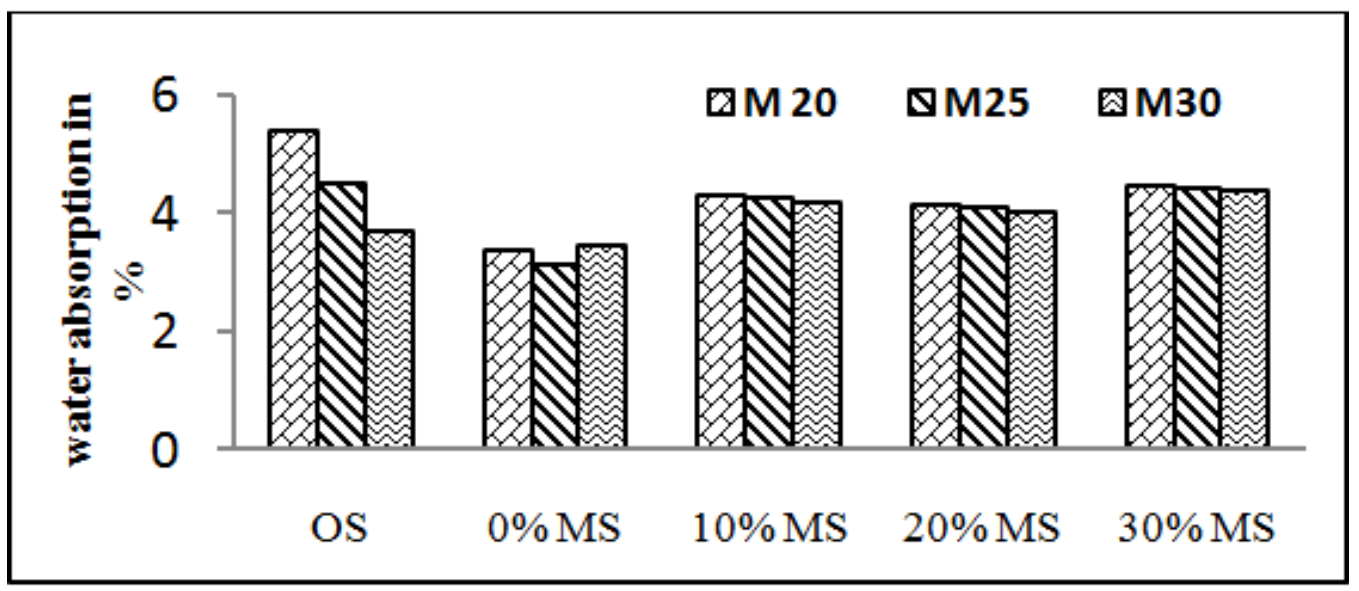

Figure 4(b): Concrete with MS.

The water absorption for offshore sand in M20 concrete was found to exceed 5 percent against the standard limit. The value was found to decline for the grade M25 andM30 while using offshore sand in concrete.

\section{Alkalinity Test}

The alkalinity of samples were tested using $\mathrm{pH}$ meter and the result is as shown in fig 5

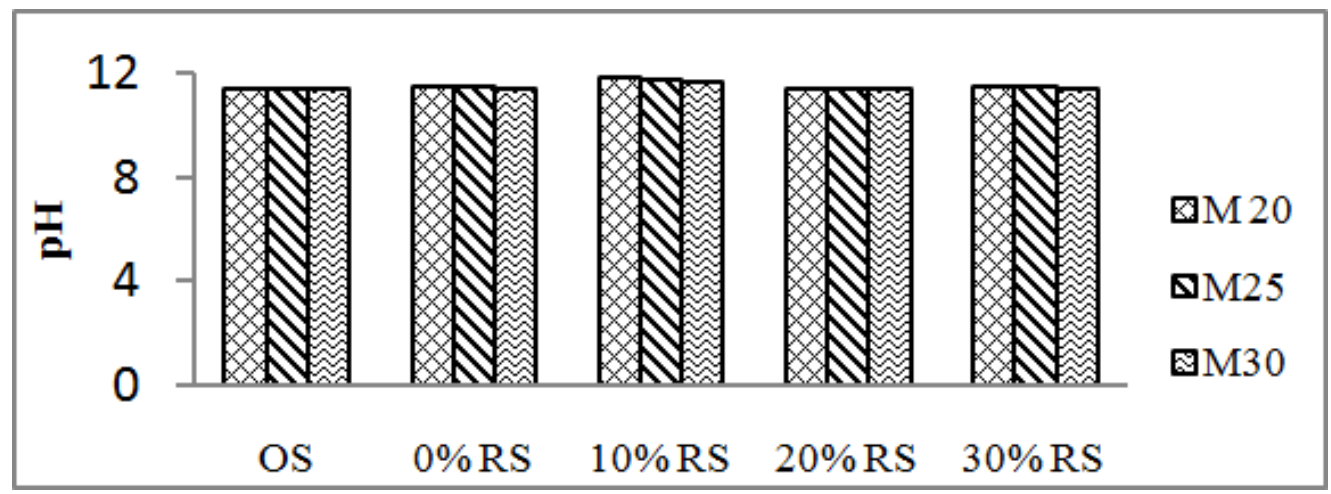

Figure 5(a): Alkalinity of RS.

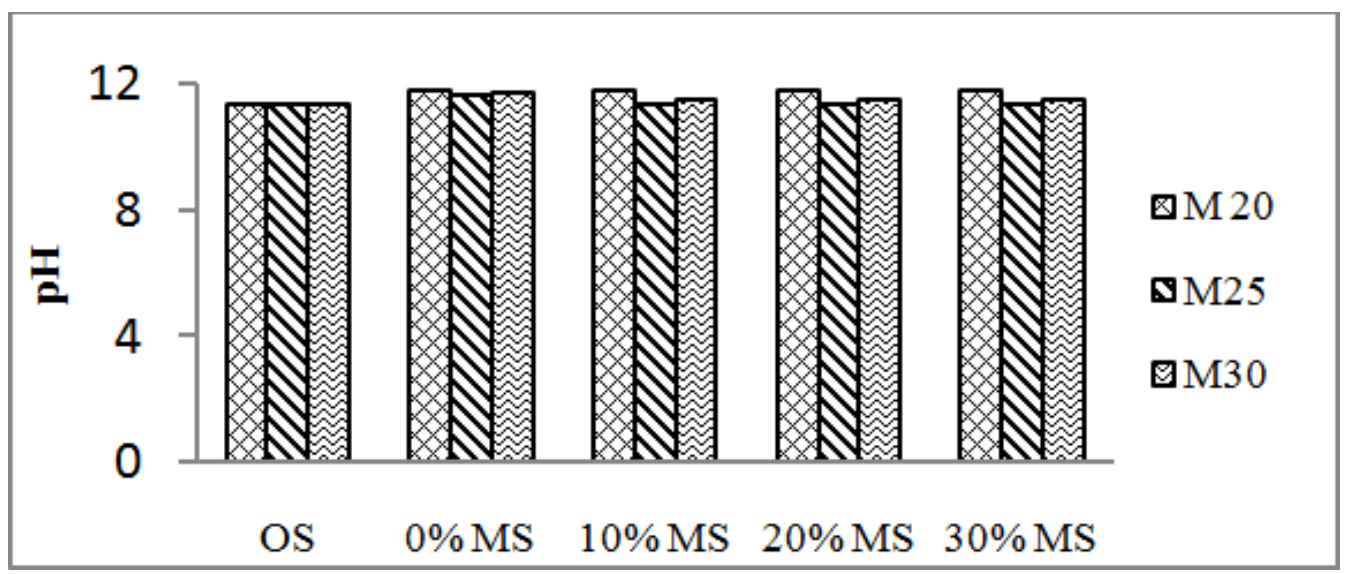

Figure 5(b): Alkalinity of MS.

The alkalinity values of all the samples satisfy the range of 9 to 12 as per the standards shown in Fig. 5(a) and 5(b). 


\section{Rapid Chloride Penetration Test}

The average current that passes through different specimens of concrete was determined. The test results of different samples are shown in Fig 6

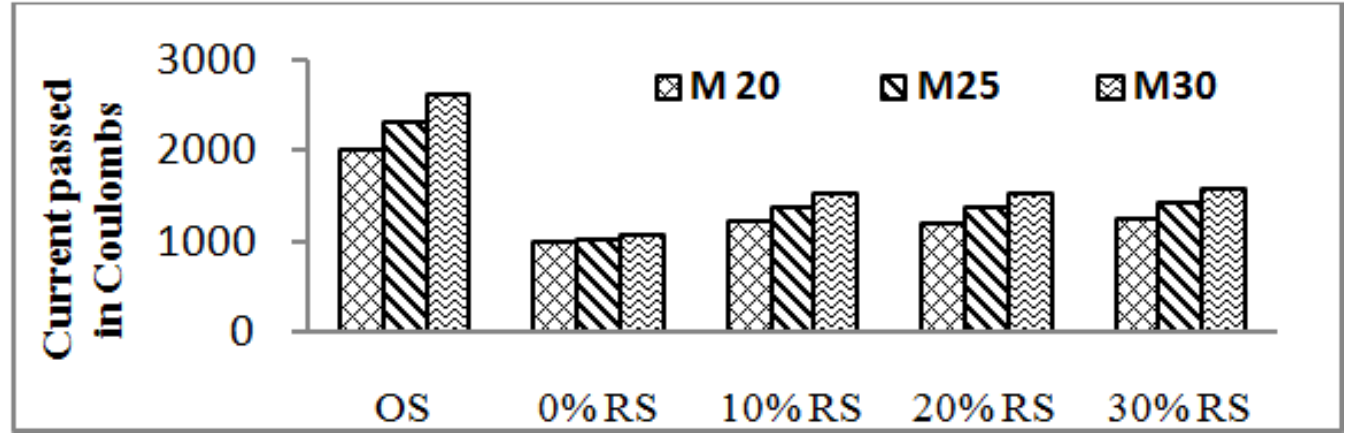

Figure 6(a): RCPT for Concrete with RS.

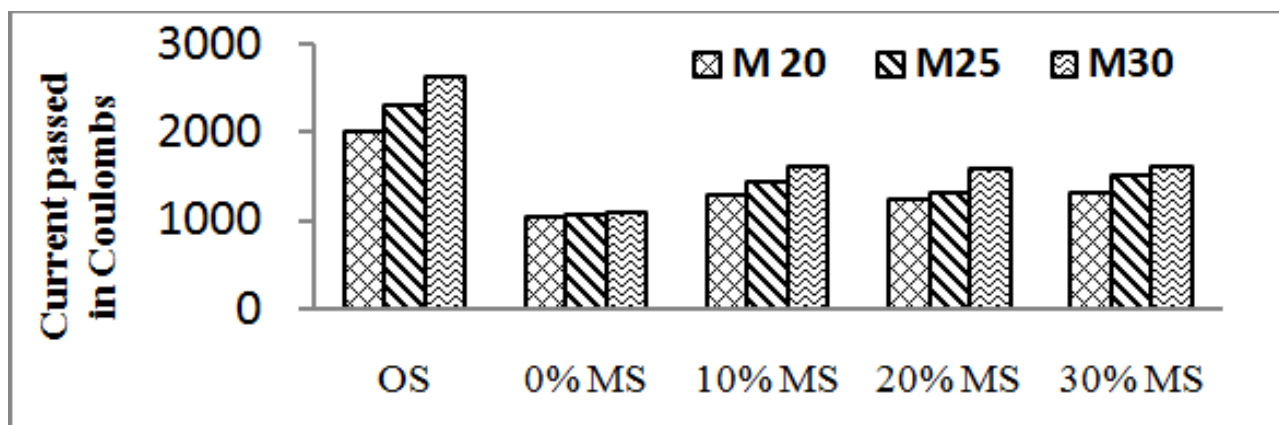

Figure 6(b): RCPT for Concrete with MS.

From the experimental result it was found that all the specimens satisfy ASTM limits as the average current flowing through conventional concrete specimen was at the range of 1000 to 4000 as per ASTM C 1202.

\section{Compressive Strength}

Fig. 7 and 8 shows the 28-day compressive strength results for cube and cylinder specimens.

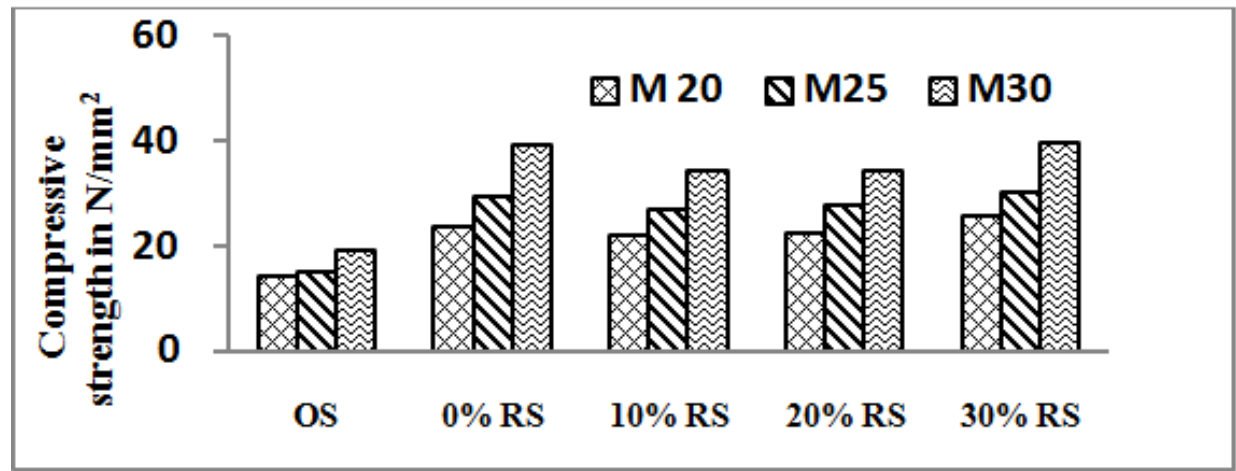

Figure 7(a): Cube Compressive Strength of Concrete with RS at 28 Days. 


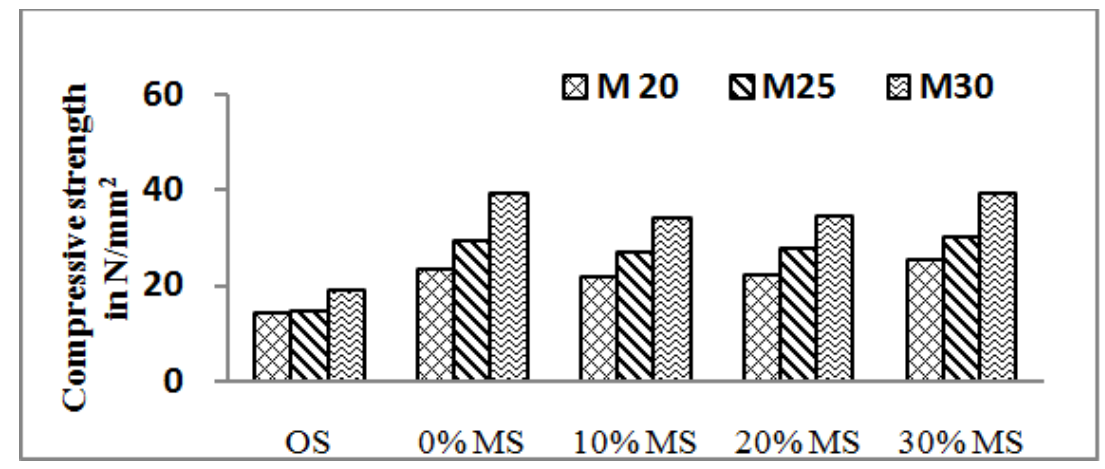

Figure 7(b): Cube Compressive Strength of Concrete with MS at 28 Days.

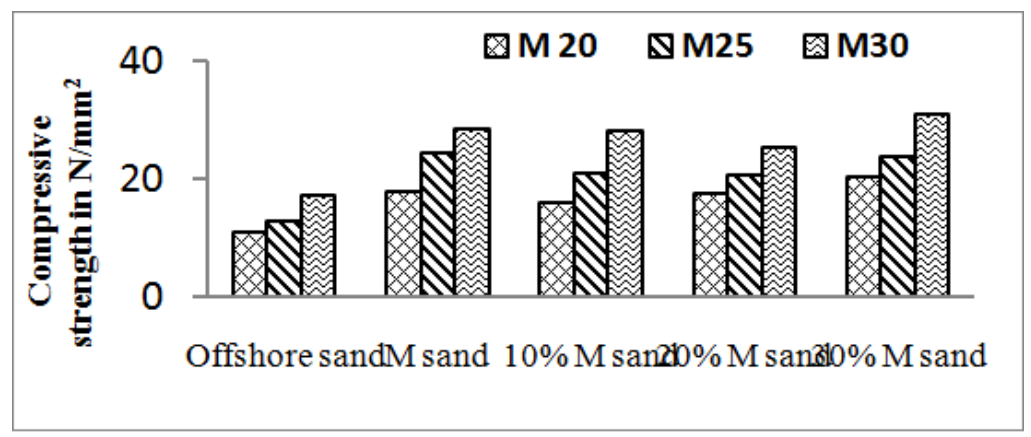

Figure 8: Cylinder Compressive Strength of Concrete with MS at 28 Days.

\section{Flexural Strength}

Flexural strength of different samples was determined by conducting two point loading test as per ASTM C 293. The flexural strength is expressed as Modulus of Rupture in MPa. Fig 9 shows the results for flexural strength for beam specimens.

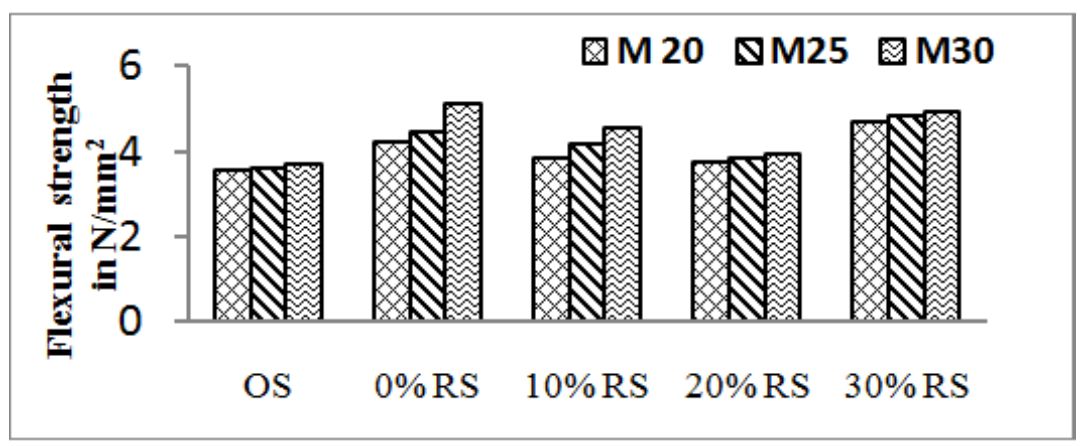

Figure 9(a): Flexural Strength of Beam with RS.

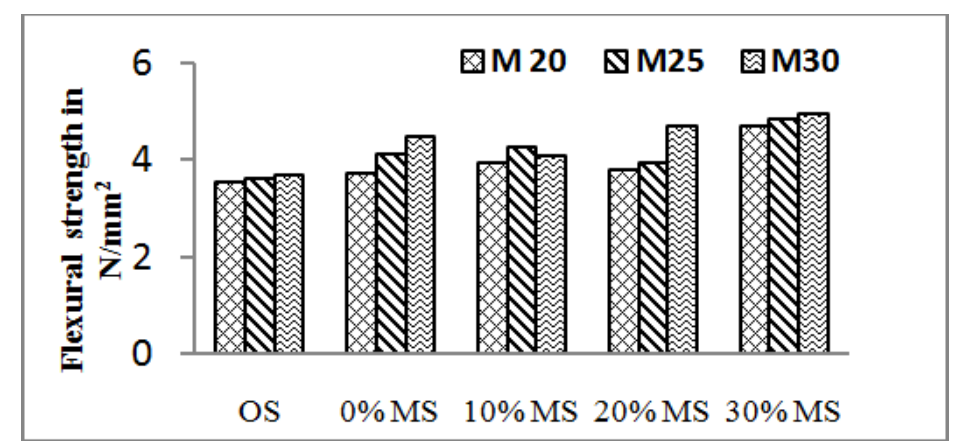

Figure 9(b): Flexural Strength of Beam with MS. 


\section{TEST RESULTS AND DISCUSSION}

\section{Percentage Water Absorption for Different Grades of Concrete}

Based on the test results for concrete with partial replacement of River sand and $\mathrm{M}$ sand with offshore sand, an equation was attained to illustrate the difference in compressive strength with regard to water absorption. The equation is

$$
\% \text { of water absorption }=3.81 e^{-0.004 \tau_{c k}}-0.2
$$

The water absorption values obtained using the above equation and presented in Table 2 . The experimental values were found to be in agreement with the theoretical values.

Table 2: Experimental vs. Theoretical Values

\begin{tabular}{|c|c|c|c|c|}
\hline \multirow{2}{*}{ Mix } & \multicolumn{2}{|c|}{ Experimental Results } & \multicolumn{2}{c|}{ Theoretical Results } \\
\cline { 2 - 5 } & Graded OS with RS & Graded OS with MS & Graded OS with RS & Graded OS with MS \\
\hline M 20 & 3.18 & 4.12 & 3.53 & 3.51 \\
\hline M 25 & 3.14 & 4.08 & 3.56 & 3.54 \\
\hline M 30 & 3.12 & 4.01 & 3.58 & 3.59 \\
\hline
\end{tabular}

\section{Percentage Water Absorption and Rapid Chloride Penetration Test}

Based on the results of concrete experiments with river sand and $\mathrm{M}$ sand replaced with offshore sand, an equation was obtained to display the percentage variance of the cube compressive force with regard tochloride absorption.

The equation is

$$
\% \text { of chloride absorption }=-25 \times 10^{-5} f_{c k}+3.93
$$

Substituting the values of compressive strength in the above equation the percentage of chloride absorption values were determined as shown in Table 3.

Table 3: Experimental vs. Theoretical Values

\begin{tabular}{|c|c|c|c|c|}
\hline \multirow{2}{*}{ Mix } & \multicolumn{2}{|c|}{ Experimental Results } & \multicolumn{2}{c|}{ Theoretical Results } \\
\cline { 2 - 5 } M 20 & Graded OS with RS & Graded OS with MS & Graded OS with RS & Graded OS with MS \\
\hline M 25 & 3.18 & 4.12 & 3.63 & 3.62 \\
\hline M 30 & 3.14 & 4.08 & 3.59 & 3.60 \\
\hline
\end{tabular}

It was found that the average variation between the experimental and Theoretical values were less than 10Percent

\section{Compressive Strength vs. Flexural Strength}

An equation for offshore sand replaced with river sand and $M$ sand was obtained based on the test results to show the variation of cube compressive strength with respect to flexural resistance. The equation is

$$
f_{c k}=2.15 f_{b}-3.43
$$

Using the above equation the compressive strength values were obtained using the experimental values of flexural strength as shown in Table 4. It was observed that the obtained values were closer and the deviation is marginal. 
Table 4: Experimental vs. Theoretical Values

\begin{tabular}{|l|c|c|c|c|}
\hline \multirow{2}{*}{ Mix } & \multicolumn{2}{|c|}{ Experimental Results } & \multicolumn{2}{c|}{ Theoretical Results } \\
\cline { 2 - 5 } & Graded OS with RS & Graded OS with MS & Graded OS with RS & Graded OS with MS \\
\hline M 20 & 4.71 & 4.67 & 4.91 & 4.55 \\
\hline M 25 & 5.25 & 5.25 & 5.79 & 4.97 \\
\hline M 30 & 5.86 & 5.78 & 6.58 & 5.39 \\
\hline
\end{tabular}

\section{CONCLUSIONS}

- Fractional substitutions of offshore sand with River sand and M sand increases the sand quality for concrete use.

- The chlorides present in offshore sand was marginally higher that can be overlooked.

- The size of offshore sand shells below $5 \mathrm{~mm}$ and above $10 \mathrm{~mm}$ is 1.1 per cent, well within the BS $882: 1992$ limits.

- The organic content in offshore sand was in agreement with ASTM D 2974 limits.

- The specimens cast replacing M sand with offshore sand by 20 percent was found to be comparable to the concrete specimens cast with river sand whereas for all other proportions it was lower.

- The R C P T results show that the average current passing through the concrete made with off shore sand was within the range specified by ASTM for conventional concrete. Hence the extent possibility for corrosion is less.

- The percentage of water absorption was generally higher for concrete specimens made with offshore sand, and the value was found to decrease for the concrete specimens cast using the offshore sand with $20 \%$ of river sand as partial replacement.

- The alkalinity of all the specimens was within the permissible limits. Hence the possibility of corrosion is less.

- From this study it is evident that offshore sand can be used as partial replacement to river sand and M sand to be used as fine aggregate in concrete. The sand requires washing to extract organic matter which cannot removed by mere sieving.

\section{REFERENCES}

1. V.Kanthe, S Deo, M Murmu (2018), “Combine use of Fly ash and rice husk ash in concrete to improve its properties”, IJE TRNASACTIONS A : Basics Vol.31, No.7, 1012 -1019.

2. Ajith Kumar. S, Gunalan.p, Manivel.K, M.Bhuvaneswari, and Manoj Babu.M (2018), Experimental Study On Partial Replacement Of Sea Sand As Fine Aggregate In Concrete”, International Journal of Science and Engineering Research, Vol 6 Issue 4

3. Jesus S Meylin, S. JansiSheela, \& S. Sidhardhan (2017), "Study on sea sand as a partial replacement for fine aggregate”, Journal of Advances in Chemistry, Vol 13

4. S.E Mousavi (2016), "Effect of moisture content on shear strength of offshore clay interface steel surface", IJE TRNASACTIONS B: Applications Vol.29, No.2, 183-191.

5. K. Godwin, M. Murugan, R. Mahendran, and T. GnanaSelvan (2016), “Experimental Study On Concrete Using Sea Sand As Fine Aggregate”, International Journal of Scientific \& Engineering Research, Volume 6, Issue 4. 
6. GunupudiYalamesh, KandagaddalaRevanth Kumar, and Ramakrishnan K (2015), "Study of Strength of Concrete by Partially Replacing Fine Aggregate with Bottom Ash and Marine Sand”, International Journal of ChemTech Research, ISSN: 09744290,Vol.8, No.8, pp 161-166

7. Madan Mohan Reddy, Sivaramulu Naidu D., and VijayaSekhar Reddy M (2013), "Studies on chemical and geotechnical properties of marine Sand”, International Journal of Advanced Research in Engineering and Technology.

8. C. T. Ariyawansa, D. A. R. Dolage, and M. G. S. Dias (2013), "Offshore Sand as a Fine Aggregate for Concrete Production", British Journal of Applied Science \& Technology, 3(4): 813-825

9. D. A. R. Dolage, M. G. S. Dias and C. T. Ariyawansa(2013) "Offshore Sand as a Fine Aggregate for Concrete Production", British Journal of Applied Science \& Technology 3(4): 813-825, 2013

10. S.Isalm, M Islam, B Chandra Mondal (2012), "Deterioration of Concrete in ambient Marine Environment", IJE TRNASACTIONS B :Applications Vol.25, No.4, 289-301.

11. Agullo L, Etxeberria M, Limeira J, and Molina D (2011), "Mechanical and durability properties of concrete made with dredged marine sand", Journal of Construction and Building Materials; 25:4165-4174

12. J. Limeira, L. Agullo, M. Etxeberria2009, "Dredged marine sand in concrete: An experimental section of a harbor Pavement , , Construction and Building Materials 24 (2010) 863-870

13. W.P.S. Dias, G.A.P.S.N. Seneviratne, S.M.A. Nanayakkara 2007 "Offshore sand for reinforced concrete", Construction and Building Materials 22 (2008) 1377-1384

14. Rajagopal, Deepthy, and Mathews M. Paul. "Durability study of self-compacting concrete using manufactured sand." IMPACT: International Journal of Research in Engineering \& Technology (IMPACT: IJRET) 2.9 (2014): 45-50.

15. Cheema, R. M., Deepinder Singh Aulakh, and S. Arvesh Kumar. "Durability of cement stabilized pond ash." International Journal of Civil, Structural, Environmental and Infrastructure Engineering Research and Development (IJCSEIERD) 6.2 (2016): 17-28.

16. Shankar, K. Uma, and K. Suganya. "Durability study of structural elements using fly ash aggregates." BEST: International Journal of Management, Information Technology and Engineering (BEST: IJMITE) 2.1 (2014): 1-6.

17. Morge, R. P., and Dhananjay K. Parbat. "Optimum replacement of natural sand with artificial sand; in concrete." International Journal of Civil, Structural, Environmental and Infrastructure Engineering Research and Development (IJCSEIERD) 3.5 (2013): 91-98.

18. Shalabi, Faisal I., and Talat A. Bader. "Effect of sand densification due to pile-driving on pile resistance." International Journal of Civil Engineering (IJCE) 3.1 (2014): 17-30. 